J. Clin. Chem. Clin. Biochem.

Vol. 24,1986, pp. $73-88$

(C) 1986 Walter de Gruyter \& Co. Berlin - New York

\title{
Bronchoalveolar Lavage Fluid and Plasma Proteins, Chemiluminescence Response and Protein Contents of Polymorphonuclear Leukocytes from Blood and Lavage Fluid in Traumatized Patients ${ }^{1}$ )
}

\author{
By A. Dwenger, G. Schweitzer
}

Abteilung für Klinische Biochemie der Medizinischen Hochschule Hannover and

G. Regel

Klinik für Unfallchirurgie der Medizinischen Hochschule Hannover

(Received August 26/November 18, 1985)

Summary: The technique of bronchoalveolar lavage was used to obtain serial samples of lavage every two days from non-contused lung areas of seven traumatized patients and four normals; blood was drawn simultaneously. Urea, total protein, albumin, $\alpha_{1}$-proteinase inhibitor, $\alpha_{2}$-macroglobulin, lactate dehydrogenase, $\beta-\mathrm{N}$-acetyl-glucosaminidase, myeloperoxidase, and elastase enzyme activity, as well as complexed and total elastase concentrations were determined in bronchoalveolar lavage fluids and plasma samples. Lavage fluid cell pattern was counted. Polymorphonuclear leukocytes were isolated from lavage fluids and blood samples. Granulocyte contents of elastase enzyme activity, complexed and total elastase concentrations, and myeloperoxidase and lactate dehydrogenase activity were determined. Polymorphonuclear leukocyte stimulatory functions were measured by luminol-enhanced chemiluminescence.

The following results were obtained for the patient group: Patterns of lavage fluid cells were shifted in favour of polymorphonuclear leukocytes and lymphocytes. The protein determinations of bronchoalveolar lavage fluids and plasma samples gave information about the extent of alterations of permeability of the capillaryinterstitial-alveolar space (albumin/urea and $\alpha_{1}$-proteinase inhibitor/urea ratios) as well as about the amounts of cytoplasmic and lysosomal enzymes released by phagocytes (lactate dehydrogenase/urea, $\beta-\mathrm{N}$-acetylglucosaminidase/urea, elastase/urea ratios). Polymorphonuclear leukocytes isolated from bronchoalveolar lavage fluids contained a decreased content of myeloperoxidase and elastase enzyme activities and total elastase concentration; the content of complexed elastase was found to be increased more than 100 fold. From chemiluminescence measurements there was evidence for decreased zymosan-induced stimulatory function, while the photon emission rate of polymorphonuclear leukocytes after passage into the alveolar space was increased.

Bronchoalveolar Lavage- und Plasma-Proteine, Chemilumineszenz und Proteinkonzentrationen polymorphkerniger Leukocyten aus Blut und Lavage bei Traumapatienten

Zusammenfassung: Mit Hilfe der bronchoalveolären Lavage-Technik wurden in zweitägigen Abständen lösliche und zelluläre Komponenten aus kontusionsfreien Lungenarealen traumatisierter Patienten und Gesunder gewonnen sowie venöse Blutproben entnommen. In Lavage-Flüssigkeiten und Plasmaproben wurden Harnstoff, Gesamtprotein, Albumin, $\alpha_{1}$-Proteinasen-Inhibitor, $\alpha_{2}$-Makroglobulin, Lactatdehydrogenase, $\beta$-N-Acetylglucosaminidase, Myeloperoxidase, Elastase-Aktivität sowie komplexierte und totale Elasta-

1) This work was supported by the 'Deutsche Forschungsgemeinschaft', project II B 6 
se-Konzentrationen gemessen, die Zellmuster in Lavage-Flüssigkeiten ermittelt, Granulocyten aus Blut und Lavage-Flüssigkeiten isoliert, ihre Gehalte an Elastase-Aktivität, komplexierter und totaler ElastaseKonzentration, Myeloperoxidase- und Lactatdehydrogenase-Enzymaktivitäten ermittelt sowie ihre Stimulierbarkeit mit Hilfe der Luminol-verstärkten Chemilumineszenz gemessen.

Folgende Ergebnisse wurden für die Patientengruppe gefunden:

Die Zellmuster in bronchoalveolärer Lavage-Flüssigkeit sind zugunsten polymorphkerniger L'eukocyten und Lymphocyten verschoben. Die Proteinmessungen in Lavage-Flüssigkeiten und Plasma geben über das Ausmaß der Permeabilitätsveränderungen der kapillär-interstitiell-alveolären Strecke Auskunft (Albumin/Harnstoffund $\alpha_{1}$-Proteinasen-Inhibitor/Harnstoff-Relationen) sowie zur Menge der aus Phagocyten freigesetzten cytoplasmatischen und lysosomalen Enzyme (Lactatdehydrogenase/Harnstoff-, $\beta$-N-Acetyl-glucosaminidase/ Harnstoff-, Elastase/Harnstoff-Relationen). Aus Lavage-Flüssigkeiten isolierte polymorphkernige Leukocyten weisen erniedrigte Gehalte an Myeloperoxidase- und Elastase-Aktivitäten und an totaler ElastaseKonzentration auf, der Gehalt an komplexierter Elastase ist mehr als 100-fach erhöht. ChemilumineszenzMessungen zeigen, daß nach Passage der Blut/Luft-Barriere das Ausmaß der Zymosan-vermittelten Stimulierbarkeit polymorphkerniger Leukocyten geringer ist, die Photonenemission dagegen schneller erfolgt.

\section{Introduction}

Bronchoalveolar lavage methods have been used to characterize inflammatory and immune processes of the lower respiratory tract in different chronic and acute forms of pulmonary diseases. Evaluation of lavage fluid serves to assess composition, concentrations and functions of soluble and cellular bronchoalveolar lavage fluid components for diagnostic, prognostic and therapeutic purposes (1). Furthermore, from the data already acquired by this technique, it is apparent that bronchoalveolar lavage has and will continue to yield major insights into the pathogenesis, staging, and therapy decisions involved in pulmonary disorders (2).

Inflammatory processes are the product of cellular stimulation and humoral effects with the common pathological result of plasma exudation and leukocyte sequestration and accumulation. A variety of severe physiçal, chemical or infectious insults are frequently followed by the Adult Respirātory Distress Syndrome. The precise pathophysiological events that contribute to this syndrome formation are largely unknown. However, substantial evidence strongly suggests that the pulmonary lesions known to be associated with the Adult Respiratory Distress Syndrome may result from polymorphonuclear leukocyte sequestration in the pulmonary mictocirculation and their migration across the vascular-alveolar barrier. An increased release of toxic and damaging products like lysosomal proteinases as well as disturbances of the proteinase-proteinase inhibitor imbalance have been discussed as possible mediators of this syndrome $(3-8)$.

In a prospective study we addressed our attention to the serial evaluation of soluble and cellular biochemical factors and events that take place at the site of inflammation in developing lung injury in traumatized patients. The present investigation was performed to evaluate a procedure, firstly for getting information about some pathomechanisms of lung inflammation and injury, especially about markers for permeability and granulocyte function alterations and secondly, hereby to establish a system for the prediction of improvement or deterioration of the patients' lung situation from the serial course.

Specifically, the protein patterns of bronchoalveolar lavage fluid and plasma were examined during posttraumatic inflammation in the lung. The enzyme content of polymorphonuclear leukocytes isolated from lavage fluid and from blood was also investigated. The granulocyte stimulatory capacity was evaluated by luminol-enhanced chemiluminescence responses of lavage and blood derived granulocytes to establish possible changes of polymorphonuclear leukocyte functions caused by biochemical events occurring during passage from the blood into the alveolar space.

\section{Materials and Methods}

Study population

A group of 7 traumatized patients predisposed to the development of the Adult Respiratory Distress Syndrome was studied. Associated injuries included blunt thoracic trauma with rib fractures, blunt abdominal trauma and multiple extremity fractures. All had suffered to some degree from an early phase of hypovolaemic shock after trauma. The clinical characteristics of the patients and their injury pattern are listed in table 1 . A control group $(n=4)$ was also studied. After informed consent patients undergoing operative removal of osteosynthetic foreign bodies were lavaged shortly after intubation and before the beginning of the operative procedure.

Bronchoscopy was performed routinely every 48 hours for therapeutic reasons, and additionally the non-contused part of the lung was lavaged under the described-eonditions. 
Tab. 1. Clinical characteristics of study population selected

\begin{tabular}{|c|c|c|}
\hline Group & Clinical characteristics & Time of lavage procedure (d) \\
\hline $\begin{array}{l}\text { Normals } \\
(n=4)\end{array}$ & $\begin{array}{l}\text { Patients undergoing operative removal of osteosynthetic } \\
\text { foreign bodies }\end{array}$ & After intubation; before surgery \\
\hline \multicolumn{3}{|l|}{$\begin{array}{l}\text { Traumatized patients } \\
(n=7)\end{array}$} \\
\hline No. 1 & $\begin{array}{l}\text { Subtotal amputation of the arm with right humerus fracture; } \\
\text { right } 2-8 \text { rib fractures; right lung contusion; right } \\
\text { haematothorax; right tibial fracture }\end{array}$ & $1,2,4,8,10$ \\
\hline No. 2 & $\begin{array}{l}\text { Left clavicular fracture; left } 4-6 \text { rib fractures; left lung } \\
\text { contusion + haemato-pneumothorax; right proximal femur } \\
\text { fracture; distal right tibial fracture; left proximal tibial } \\
\text { fracture }\end{array}$ & $2,4,8$ \\
\hline No. 3 & $\begin{array}{l}\text { Blunt thoracic trauma; right femur fracture; right tibial } \\
\text { fracture }\end{array}$ & $1,4,6,8$ \\
\hline No. 4 & Left lung contusion; left $1-2$ rib fracturcs & 1,4 \\
\hline No. 5 & $\begin{array}{l}\text { Skull fracture; cerebral contusion; right } 2-9 \text { rib fractures; } \\
\text { right lung contusion and haemato-pneumothorax }\end{array}$ & 1,4 \\
\hline No. 6 & $\begin{array}{l}\text { Left lung contusion with endobroncheal bleeding; left scapula } \\
\text { fracture; left proximal humerus fracture }\end{array}$ & $1,3,5$ \\
\hline No. 7 & $\begin{array}{l}\text { Left lung contusion with endobroncheal bleeding; left } 4-6 \\
\text { rib fractures, haemato-pneumothorax }\end{array}$ & $1,4,6$ \\
\hline
\end{tabular}

\section{Bronchoalveolar lavage technique}

Bronchoscopy and bronchoalveolar lavage procedure were done on the normal control group immediately before surgery and on the traumatized patients at the time of their admission to the intensive care unit and thereafter at the times indicated in table 1. Lavage fluid was recovered with a modification of the method of McGuire et al. (9). Briefly, evaluation of the airways was carried out with a flexible fiberoptic bronchoscope (Olympus BF type $1 \mathrm{~T} \mathrm{10,} \mathrm{Olympus} \mathrm{Corporation} \mathrm{of} \mathrm{America,}$ New Hyde Park, N. Y.) and the tip of the bronchoscope was wedged in bronchus 4 or 5 of the right middle lobe (or lingula) of the non-contused lung. This ensured a complete blockage of a 2nd order bronchus and allowed for an isolated segmental lavage without an appreciable amount of contamination with tracheo-bronchial blood. Each lavage was performed by the injection of $40 \mathrm{ml}$ of sterile saline $(9 \mathrm{~g} / \mathrm{l})$ followed by its suction removal through the bronchoscope and collection in a sterile graduated plastic container: Quantities of $25-30 \mathrm{ml}$ were recovered. After collection of lavage fluid, sodium citrate solution $(31.3 \mathrm{~g} / \mathrm{l})$ was added in a $1: 10$ proportion to avoid coagulation. The fluid was filtered through a two-fold layer of surgical gauze and the volume was measured. After removal of a 1 or $2 \mathrm{ml}$ aliquot for differential cell counting, all of the remaining lavage fluid was divided and layered on a modified (10) two-step discontinuous Percoll gradient $(3 \mathrm{ml}$ each of 1.077 and 1.095 $\mathrm{g} / \mathrm{cm}^{3}$ densities) in four to six $13 \mathrm{ml}$ polystyrene tubes and centrifuged at $400 \mathrm{~g}$ at $22^{\circ} \mathrm{C}$ for $20 \mathrm{~min}$. The upper layers of the tubes were combined, centrifuged $(12000 \mathrm{~g}$ at room temperature for $2 \mathrm{~min}$ ) to remove remaining cells, and several $1 \mathrm{ml}$ aliquots were frozen at $-70^{\circ} \mathrm{C}$ until determination of the contents. One aliquot was diluted with an equal volume of normal plasma for the immunological determination of the total elastase content. Granulocytes were harvested from all tubes, combined, washed twice with phosphate buffered saline by centrifugation $\left(600 \mathrm{~g}\right.$ for $10 \mathrm{~min}$ at $22^{\circ} \mathrm{C}$ ), resuspended with $200-500 \mu$ of Minimal Essential Medium buffer solution and counted using a Neubauer haemocytometer after cell staining with Türk's solution.

The resultant polymorphonuclear leukocyte suspension was used for chemiluminescence measurements and protein determinations.
Prevention of bronchoalveolar lavage fluid contamination

Only lung segments without bronchoscopic evidence of contusion were studied with bronchoalveolar lavage in order to avoid the contamination of lavage fluid with blood.

False positive lavage protein concentrations are quite often detected if more than $20 \mu \mathrm{l}$ or blood are detected in lavage fluid samples of about $30 \mathrm{ml}$. Assuming a contamination of 20 $\mu \mathrm{l}$ of blood in $30 \mathrm{ml}$ of lavage fluid and taking into account the normal concentrations of different proteins in plasma and bronchoalveolar lavage fluid, one can calculate an increase up to 1.5 fold for the concentrations of several proteins in lavage fluid. Therefore, a check of blood contamination was performed as follows: after harvesting granulocytes by Percoll gradient centrifugation (see above) red blood cell pellcts from all the centrifugation tubes were combined, lysed by $1 \mathrm{ml}$ of distilled water and haemoglobin measured by the cyanomethaemoglobin method with Drabkin's reagent. If more than $3 \mathrm{~g} / \mathrm{l}$ haemoglobin in the lysate were found, it was assumed that the original lavage sample had been contaminated with more than $20 \mu \mathrm{l}$ of blood, and it was discarded.

Differential counts of bronchoalveolar lavage fluid cells

Lavage cells of a 1 or $2 \mathrm{ml}$ aliquot of filtered lavage fluid (see above) were concentrated by centrifugation $\left(600 \mathrm{~g}\right.$ at $22^{\circ} \mathrm{C}$ for $10 \mathrm{~min}$ ) and resuspended with $0.1 \mathrm{ml}$ of Minimal Essential Medium buffer solution. Smears were prepared on a microscope glass slide, and stained with May-Grünwald and Gicmsa solution according to Pappenheim. Differential counts were then made using a Universal microscope (Zeiss, Oberkochen, FRG) and immersion oil, magnification $\times 1000$. The fractions of lymphocytes, alvcolar macrophages and polymorphonuclear leukocytes were determined.

\section{Polymorphonuclear leukocyte isolation from blood}

Within one hour before or after the lavage procedurc, venous blood was drawn and anticoagulated by the addition of 31.3 
g/l sodium citratc solution $(9 \mathrm{vol}$ of blood +1 vol of citratc solution). Four $\mathrm{ml}$ were layered on a two-step discontinuous Percoll gradient (densitics of 1.077 and $1.095 \mathrm{~g} / \mathrm{cm}^{3}$ ) and processed as described in the section "bronchoalveolar lavage technique'. The resulting granulocyte suspension was used for the measurements of chemiluminescence and protein concentrations.

\section{Plasma samples}

An aliquot of the venous blood samples (see above section) was removed and centrifuged at $800 \mathrm{~g}$ for $15 \mathrm{~min}$ at $22^{\circ} \mathrm{C}$. The resulting plasma was kept frozen at $-70^{\circ} \mathrm{C}$ until use.

\section{Polymorphonuclear leukocyte lysis}

In order to measure the protein contents of granulocytes (except for total elastase) 1 volume of the granulocyte suspension (isolated from lavage fluid and citrate blood, respectively) was diluted with 1 volume of lysing mixture $(1.5 \mathrm{~g}$ of digitonin and $100 \mathrm{ml}$ of distilled water containing $1 \mathrm{~g}$ of NP 40 were stirred for 3 hours, the undissolved digitonin was allowed to settle and the clear supernatant was used), sonicated for $10 \mathrm{~s}$ in ice (position 60 on the Braun-Sonic 125 sonifier, Quigley-Rochester, Inc. N.Y., U. S. A.), aliquoted and frozen at $-70^{\circ} \mathrm{C}$ until determination. For total elastase content 1 volume of granulocyte suspension was diluted with 1 volume of normal plasma (to complex free elastase and to avoid adsorption of the basic protein elastase on plastic material) and 2 volumes of the above lysing mixture. After sonication for $10 \mathrm{~s}$, aliquots were frozen at $-70^{\circ} \mathrm{C}$ until determination. After thawing, these lysates were sonicated for $10 \mathrm{~s}$ in ice, and the samples were then measured without previous centrifugation.

\section{Test procedures}

\section{Protein}

The total protein concentrations of plasma samples and bronchoalveolar lavage fluid were determined with the biuret method according to Kingsley (11). Bovine serum albumin (70 $\mathrm{g} / \mathrm{l})$ in saline $(9 \mathrm{~g} / \mathrm{l})$ served as a protein standard.

\section{Albumin}

Albumin concentrations of plasma samples and lavage fluids were measured by the bromocresol green method according to Schirardin \& Ney (12). A $70 \mathrm{~g} / \mathrm{l}$ bovine serum albumin in saline $(9 \mathrm{~g} / \mathrm{l})$ standard solution was used.

\section{Urea}

Urea concentrations of lavage fluid and plasma samples were determined enzymatically with the test combination 'Harnstoff S' (Boehringer-Mannheim, FRG).

\section{$\alpha_{1}$-Proteinase inhibitor ( $\alpha_{1}$-antitrypsin) and $\alpha_{2}$-macroglobulin}

Both proteins were determined in lavage fluid and plasma samples nephelometrically using reagent sets, protocols and instrumentation of Immuno Diagnostika $\mathrm{GmbH}$, Heidelberg, FRG.

\section{Myeloperoxidase}

The activity of myeloperoxidase was determined photometrically according to Henson et al. (13) with $\mathrm{H}_{2} \mathrm{O}_{2}$ and o-dianisid- ine dihydrochloride as substrates. 1 unit of myeloperoxidase was defined as the activity that catalysed the reaction of $1 \mu \mathrm{mol}$ of $\mathrm{H}_{2} \mathrm{O}_{2}$ per minute under the test conditions employed.

\section{$\beta$-N-Acetyl-glucosaminidase}

The enzyme activity was measured fluorimetrically according to Yatziv et al. (14) with 4-methylumbelliferyl- $N$-acetyl- $\beta$ - $D$ glucosaminide as a substrate and 4-methylumbelliferone as a standard. 1 unit of $\beta$-N-acetyl-glucosaminidase was defined as the activity that catalysed the reaction of $1 \mu \mathrm{mol}$ of substrate per minute under the test conditions employed. Fluorescence was measured with a Model RF-510 spectrofluorophotometer (Shimadzu, Japan).

\section{Lactate dehydrogenase}

The lactate dehydrogenase activities of lavage fluid, plasma and lysate samples were determined with the test combination 'LDH opt.' (Boehringer-Mannheim, FRG).

\section{Elastase activity}

Granulocyte elastase in bronchoalveolar lavage fluid, plasma and lysate samples was determined using the protocol and the reagents of Kabi Diagnostica. The substrate pyroGlu-Pro-ValpNA (S 2484, Kabi Diagnostica, Sweden) was used in the initial rate method, recording the absorbance change at $405 \mathrm{~nm}$ and $37^{\circ} \mathrm{C}$. 1 unit of elastase activity was defined as the substrate turnover of $1 \mu \mathrm{mol} / \mathrm{min}$ under the test conditions employed.

\section{Elastase concentration}

The immunological determination of elastase concentrations in lavage fluid, plasma and lysate samples was performed with the enzyme immunoassay test combination 'PMN Elastase' (E. Merck-Darmstadt, FRG). Lavage fluid and plasma samples were measured with and without the addition of normal plasma, to investigate the ratio of complexed to free elastase. The values were corrected for dilution and the elastase content of added normal plasma.

\section{Haemoglobin}

The haemoglobin concentration of erythrocyte lysates was measured by the cyanomethaemoglobin method with Drabkin's reagent.

\section{Chemiluminescence}

Luminol-enhanced chemiluminescence of isolated polymorphonuclear leukocytes was determined by employment of the six channel Biolumat LB 9505 in combination with a hardiware configuration of an Apple II plus computer, a floppy disk II, a video display and an Epson MX $82 \mathrm{~F} / \mathrm{T}$ printer (Laboratorium Prof. Dr. Berthold, Wildbad, FRG) in $3 \mathrm{ml}$ polystyrene chemiluminescence vials. For the chemiluminescence measurements the following reagents were prepared: luminol in Minimal Essential Medium Dulbecco, $22.6 \mathrm{mmol} / 1$ containing triethylamine, $40 \mathrm{mmol} / \mathrm{l}$, daily fresh preparation; zymosan $A$, washed twice with phosphate buffered saline, once with Minimal Essential Medium (centrifugation at $800 \mathrm{~g}$ for $10 \mathrm{~min}$ at $22^{\circ} \mathrm{C}$ ) and resuspended in Minimal Essential Medium, $100 \mathrm{~g} / \mathrm{l}$, frożen in aliquots at $-70^{\circ} \mathrm{C}$. Chemiluminescence measurements were performed at $37^{\circ} \mathrm{C}$ with prewarmed reagents. Chemiluminescence reaction mixtures were composed as. follows (volumes in $\mu l)$ : 


\begin{tabular}{lllll}
\hline & $\begin{array}{l}\text { Channel 1/2 } \\
\text { 'stimulation 1' } \\
\text { (CL 1) }\end{array}$ & $\begin{array}{l}\text { Channcl 3/4 } \\
\text { 'stimulation 2' } \\
\text { (CL 2) }\end{array}$ & $\begin{array}{l}\text { Channel 5 } \\
\text { blank 1 } \\
\text { (K 1) }\end{array}$ & $\begin{array}{l}\text { Channel 6 } \\
\text { blank 2 } \\
\text { (K 2) }\end{array}$ \\
\hline Minimal Essential Medium Dulbecco buffer solution & 500 & 520 & 520 & 540 \\
Luminol solution & 10 & 10 & -10 & - \\
Zymosan A suspension & 20 & 20 & 20 & - \\
AB plasma & 20 & - & 20 & 20 \\
Granulocyte suspension (about 25000 cells) & 20 & 20 & 10 & 5 \\
\hline
\end{tabular}

After pipetting the granulocyte suspension the chemiluminescence tubes were agitated gently, chemiluminescence measurements were started simultaneously in 6 channels, and the photon emission was recorded continuously for at least $60 \mathrm{~min}$. Two chemiluminescence parameters were calculated from the measurements:

(i) peak maximum counts/min values of stimulation reactions corrected for the corresponding blanks by subtraction and normalised to 25000 cells, and

(ii) peak time values (time in min after starting the biolumat to reach the maximum of light emission; peak time values were not corrected).

\section{Chemicals and reagents}

E. Merck-Darmstadt, FRG: Türk's solution (acetic acid gentian violet solution) for leukocyte counting; sodium hydroxide; sodium potassium tartrate tetrahydrate; cupric sulphate pentahydrate; sodium iodide; bromocresol green (3', 3", 5', 5"-tetrabromo- $m$-cresolsulphonephthalein); hydrogen peroxide $300 \mathrm{~g} / 1$ solution; sodium azide; digitonin; May-Grünwald stain; Giemsa stain; $\mathrm{N}$-2-hydroxyethylpiperazine- $\mathrm{N}$-2-ethanesulfonic acid; sodium chloride; triethylamine for synthesis; Test combination 'PMN Elastase'.

Pharmacia Fine Chemicals, Sweden: Percoll for density gradient centrifugation.

Boehringer-Mannheim GmbH, FRG: luminol (powder); Minimal Essential Medium Dulbecco for chemiluminescence with $\mathrm{N}$-2-hydroxyethylpiperazine-N-2-ethanesulfonic acid without phenol red, without glutamine; phosphate buffered saline Dulbecco; test combination 'LDH opt.'; test combination 'Harnstoff S'.

Laboratorium Prof. Dr. Berthold, Wildbad, FRG: chemiluminescence vials.

Sigma Chemical Co. St. Louis, MO, U.S. A.: zymosan A from $S$. cerevisiae yeast; o-dianisidine (3,3'-dimethoxy benzidine) dihydrochloride purified crystalline; 4-methylumbelliferyl-N-acetyl- $\beta$ - $D$-glucosaminide; 4 -methylumbelliferone; albumin, bovine fraction V, 96-99\%; Drabkin's reagent.

Fresenius-Bad Homburg, FRG: sodium citrate solution (31.3 $\mathrm{g} / \mathrm{l}$ ).

Kabi Diagnostica, Sweden: S 2484, pyroGlu-Pro-Val-pNA.

Fluka, Switzerland: Nonidet P $\mathbf{4 0}$ (ethylphenylpolyethyleneglycol, NP 40).

Immuno Diagnostika-Heidelberg, FRG: anti-human- $a_{1}$-antitrypsin from goat; anti-human- $\alpha_{2}$-macroglobulin from goat; immunoneph Reference Standard Human Proteins; immunoneph Norm Control Human Proteins; Immuno-Video-Nephelometer; polyethyleneglycol buffer concentrate $400 \mathrm{~g} / \mathrm{l}$.

Blood bank, Medizinische Hochschule Hannover: normal pooled plasma from blood of healthy donors anticoagulated with $31.3 \mathrm{~g} / 1$ sodium citrate solution $(9 \mathrm{vol}$ of blood $+1 \mathrm{vol}$ of citrate solution); $A B$ plasma, normal plasma from an $A B / R h$ pos. blood donor.

\section{Results}

\section{Differential cell counts}

Table 2 summarizes the distribution of bronchoalveolar lavage cells between lymphocytes, macrophages and polymorphonuclear leukocytes. The total number of granulocytes isolated from lavage fluids ranged between 0.06 and $10.0 \cdot 10^{6}$ cells. As compared with the composition of lavage cells in normals (macrophages 0.93 , lymphocytes 0.07 , granulocytes $<0.01$ (15)), the distribution pattern was highly shifted in favour of polymorphonuclear leukocytes for all patients. Furthermore, the lymphocyte counts were initially increased in patients 1 and 2 and tended to decrease with time.

\section{Bronchoalveolar lavage concentrations of urea and proteins}

Two different types of soluble substances were found in lavage fluid:

(I) those of vascular origin such as urea, albumin, $\alpha_{1}-$ proteinase inhibitor, and $\alpha_{2}$-macroglobulin $\left(\alpha_{2}\right.$-macroglobulin may also be secreted by alveolar macrophages) (16) that can appear in lavage fluid via diffusion from blood, and

(II) those of predominantly cellular origin from invading mobile cells (lymphocytes, macrophages, polymorphonuclear leukocytes) found after secretion or release.

Examples include lactate dehydrogenase, $\beta$-N-acetylglucosaminidase, elastase and the elastase- $\alpha_{1}$-proteinase inhibitor complex. If the urea concentrations in plasma and lavage fluid serve as an indicator of the extent of plasma exudation the difference between calculated and measured amounts of different proteins in bronchoalveolar lavage fluid should depend on their permeabilities for type (I) proteins and additionally on the extent of secretion or release by migrating and phagocytosing or dying cells for type (II) proteins. Figure 1 demonstrates this behaviour for the lavage protein concentrations in normals. The protein pattern clearly showed that the calculated amounts of total protein, albumin, $\alpha_{1}$-proteinase in- 
Tab. 2. Distribution of cells derived from bronchoalveolar lavage fluids

\begin{tabular}{|c|c|c|c|c|}
\hline \multirow[t]{2}{*}{ Patient No. } & \multirow{2}{*}{$\begin{array}{l}\text { Day of lavage } \\
\text { procedure }\end{array}$} & \multicolumn{3}{|l|}{ Fractions of } \\
\hline & & Lymphocytes & Macrophages & $\begin{array}{l}\text { Polymorphonuclear } \\
\text { leukocytes }\end{array}$ \\
\hline 1 & $\begin{array}{r}1 \\
2 \\
4 \\
8 \\
10\end{array}$ & $\begin{array}{r}0.24 \\
0.09 \\
0.07 \\
-\overline{0}\end{array}$ & $\begin{array}{r}0.15 \\
0.64 \\
0.71 \\
-\overline{0.63}\end{array}$ & $\begin{array}{c}0.61 ; \\
0.27 \\
0.22 \\
-\overline{32}\end{array}$ \\
\hline 2 & $\begin{array}{l}2 \\
4 \\
8\end{array}$ & $\begin{array}{r}0.10 \\
0.22 \\
0\end{array}$ & $\begin{array}{l}0.29 \\
0.42 \\
0.52\end{array}$ & $\begin{array}{l}0.61 \\
0.36 \\
0.48\end{array}$ \\
\hline 3 & $\begin{array}{l}1 \\
4 \\
6 \\
8\end{array}$ & $\begin{array}{r}0 . \overline{08} \\
\overline{0} \\
0.08\end{array}$ & $\begin{array}{r}0 . \overline{32} \\
\overline{-} \\
0.22\end{array}$ & $\begin{array}{r}0 . \overline{60} \\
\overline{-70}\end{array}$ \\
\hline 4 & $\begin{array}{l}1 \\
4\end{array}$ & $\begin{array}{c}0.10 \\
-\end{array}$ & $\begin{array}{r}0.40 \\
-\end{array}$ & $\begin{array}{r}0.50 \\
-\end{array}$ \\
\hline 5 & $\begin{array}{l}1 \\
4\end{array}$ & $0 . \overline{07}$ & $\overline{0 . \overline{13}}$ & $0 . \overline{80}$ \\
\hline 6 & $\begin{array}{l}1 \\
3 \\
5\end{array}$ & $\begin{array}{l}- \\
-\end{array}$ & $\begin{array}{l}- \\
-\end{array}$ & $\begin{array}{l}- \\
-\end{array}$ \\
\hline 7 & $\begin{array}{l}1 \\
4 \\
6\end{array}$ & $\begin{array}{l}0.04 \\
0.05 \\
0.08\end{array}$ & $\begin{array}{l}0.38 \\
0.48 \\
0.60\end{array}$ & $\begin{array}{l}0.58 \\
0.47 \\
0.32\end{array}$ \\
\hline
\end{tabular}

$-=$ not determined
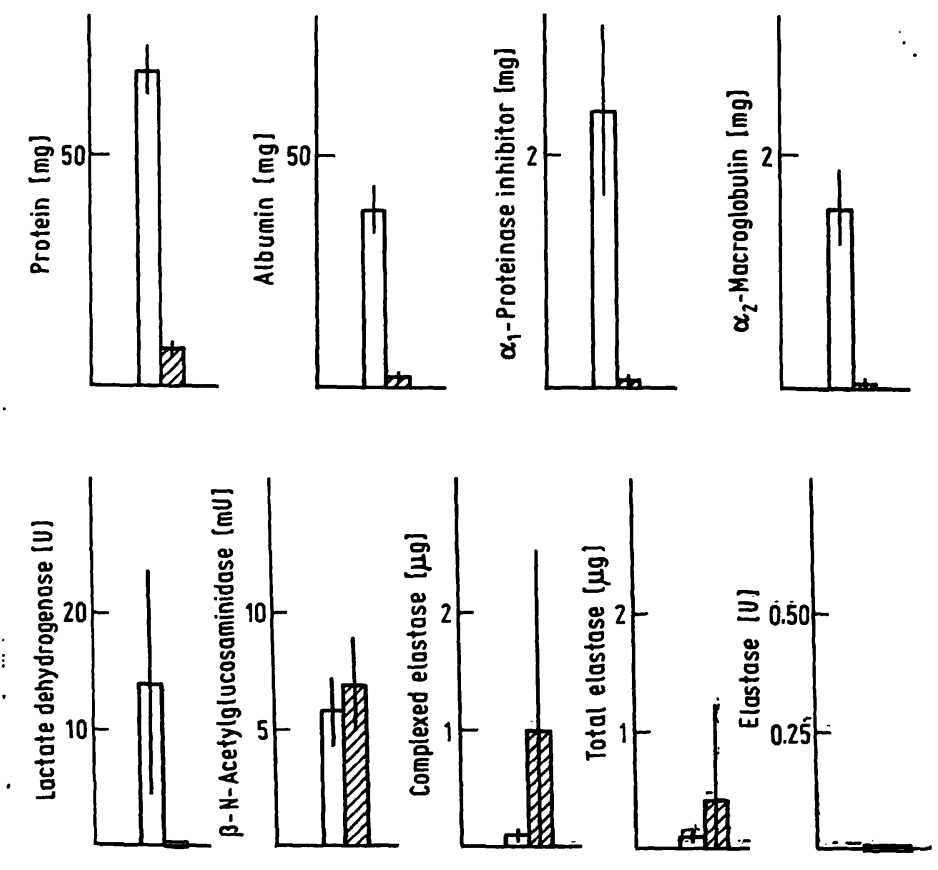

Fig. 1. Means of bronchoalveolar lavage fluid protein afnounts of normals $(\bar{x} \pm s ; n=4)$ of totally tecovered bronchoälveølar làiage fluid

$\square$ calculated

measured

Plasma and bronchoalveolar lavage fluid urea concentrations served as an exudation marker system hibitor and $\alpha_{2}$-macroglobulin in lavage fluid were higher than those measured, indicating a lower permeability of any of these proteins in comparison to urea. In contrast, the calculated amounts for $\beta-N$ acetyl-glucosaminidase, complexed elastase, and total elastase were found to be lower than those measured, presumably due to their origin from migrating cells. These migrating cells are probably predominantly polymorphonuclear leukocytes, as indicated by the granulocyte-specific elastase that would be released during constant low grade basic phagocytosis by granulocytes of airway-invading microorganisms. Enzymatically active elastase was not observed in either lavage fluid or plasma, probably due to the presence of inhibitor ( $\alpha_{1}$-proteinase inhibitor and $\alpha_{2}$-macroglobulin) in sufficient quantity to completely bind free elastase.

Figure 2 summarizes the concentrations of ten different Ofonchoalveolar lavage constituents. Lower and upper limits of concentrations determined in lavage fluids of four normals (black columns) as wẹll as limits of all lavage fluids for each individual patient are indicated. The concentrations of nearly all lavage fluid components were generally elevated for the patient group in comparison with normals, except for enzymatically determined elastase which was detected only in one lavage sample each from patients 2 and 

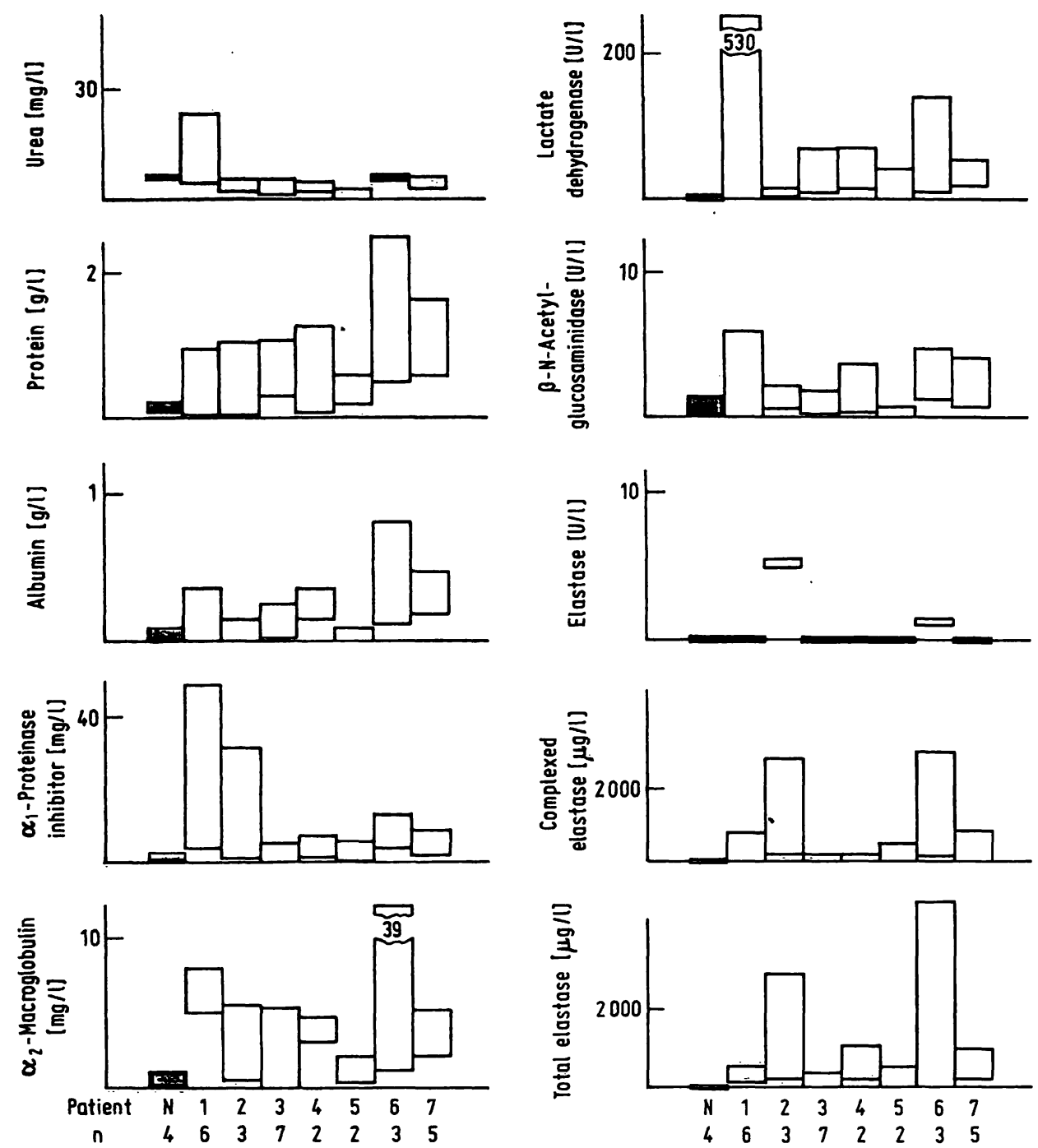

Fig. 2. Concentrations of urea and proteins in bronchoalveolar lavage fluids of normals (N; black columns) and patients. Upper and lower limits of concentrations are indicated for all bronchoalveolar lavage fluids (n) of each patient.

6, indicating incomplete inhibition by $\alpha_{1}$-proteinase inhibitor and/or $\alpha_{2}$-macroglobulin. Since an entirely suitable denominator on which to base relative changes in various protein concentrations in lavage fluids does not exist, lavage protein values can be expressed in relation to a reference substance like urea (personal communication by C.G. Cochrane, Scripps Clinic and Research Foundation, La Jolla, California, U.S. A.) that freely diffuses across biological membranes of the respiratory tract and accompanies water shifting. Its presence in bronchoalveolar lavage fluid reflects transudation from the intravascular compartment.

Bronchoalveolar lavage fluid and plasma concentrations of urea and proteins

The ratio of the concentrations of a specific substance to urea concentration in lavage fluid should decrease, compared with plasma, with the decreasing permea- bility of this substance, and vice versa. Figure 3 shows the protein/urea ratios in plasma and lavage fluid for all patients as well as for normals.

\section{Albumin}

In plasma the mean ratio for patients $(0.099)$ was somewhat lower than in normals $(0.123)$, presumably as a result of albumin loss; the lavage ratio (0.044) was found to be about 5.6 times higher than in normals $(0.0079)$ indicating an increased permeability of the blood-air barrier.

\section{$a_{1}-$ Proteinase inhibitor}

The mean plasma ratio for the patient group (14.0) was found to be higher than in normals (7.77) as a result of an acute phase 'reaction. The mean lavage ratio (1.56) was found to be 7.1 times higher than that of normals $(0.22)$, which is further evidence of increased permeability. 

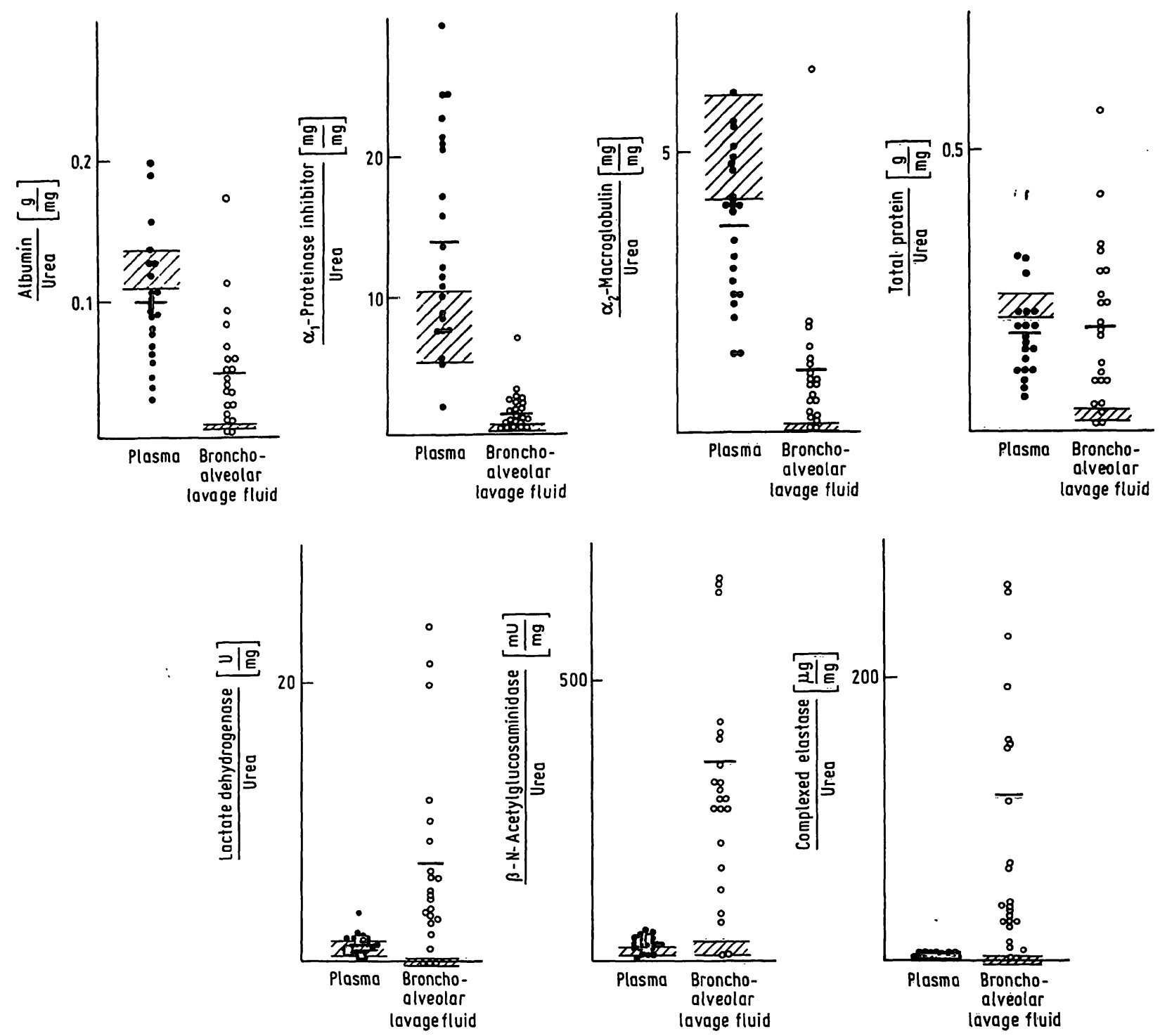

Fig. 3. Patient protein/urea ratios of bronchoalveolar lavage fluid and plasma components

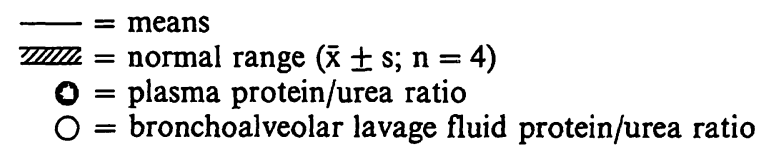

\section{$a_{2}$-Macroglobulin}

Because of an increased consumption of $\alpha_{2}$-macroglobulin, the mean plasma ratio of the patient group (3.7) was below the normal range (5.1), whereas the mean lavage ratio of patients (1.14) was elevated 16.3 fold above normals $(0.07)$. This high lavage ratio is probably partially caused by additional $\alpha_{2}$-macroglobulin secreted from alveolar macrophages, leading to an overestimation of permeability disturbances.

\section{Total protein}

Loss of total protein results in a decreased mean plasma ratio of patients (0.173) as compared to normals $(0.22)$, whereas the lavage ratio of patients
(0.185) was 7 fold higher than the normal range $(0.027)$. The mean ratios for plasma and lavage fluid were found to be nearly equal as a consequence of the contribution of type (II) lavage proteins released by inflammatory cells, thus distorting the true conditions for exact transudation calculation.

\section{Lactate dehydrogenase}

Whereas the plasma ratios of patients (1.22) and normals (1.03) were nearly equal, the mean lavage ratio increased from 0 for normals to 6.7 for the patient group, clearly indicating that this elevation could only be caused by cellular release rather than by transudation. 


\section{$\beta$-N-Acetyl-glucosaminidase}

The same was true for the corresponding $\beta-\mathrm{N}$-acetylglucosaminidase/urea ratio data. In this case the mean lavage ratio of patients (349.6) was 15.8 fold higher than that of normals (22.2) and 11 fold higher than the mean plasma ratio (31.9) in patients, indicating its cellular origin in the alveolar space.

\section{Elastase}

The above observations were further supported and confirmed by the elastase- $\alpha_{1}$-proteinase inhibitor complex. In plasma the mean ratio for patients (1.43) was 4.6 fold above normals (0.31). In lavage fluid this ratio was 77.7 fold higher and the patients' lavage ratio was 116.6 in comparison with 1.43 for plasma, i. e. a 81.5 fold increase.

Course of bronchoalveolar lavage protein/ urea ratios

In figure 4 the course of lavage protein/urea ratios is demonstrated for single patients. Large differences between individuals in the sequential course of ratios were observed.

Patient 1. There was an elevation of all ratios to a maximum on the second day with a subsequent decrease to normal values after 8 days.

Patient 2. High and increasing ratios of type (II) proteins, $\beta-\mathrm{N}$-acetyl-glucosaminidase and complexed elastase, which indicate an increased probability of damage, were accompanied by an increase of permeability markers, i. e. the albumin/urea, $\alpha_{1}$-proteinase inhibitor/urea and $\alpha_{2}$-macroglobulin/urea ratios. The survival of this patient indicated that reversible improvement at this stage of lung injury can occur.

Patient 3. During the posttraumatic course all protein/urea ratios declined toward normal ratios. As indicated by low complexed elastase/urea ratios the elastolytic burden of lung structure was negligible.

Patient 4. After an initial rise of all ratios on day 1 a rapid subsequent decrease was observed in all parameters, indicating an improvement of the permeability situation and a diminishing influence of released enzymes.

Patient 5. The behaviour of the ratio course of this patient was quite similar qualitatively to that of patient 4 , but less pronounced quantitatively.
Patient 6. This patient showed high type (I) protein ratios on day 1 and high type (II) protein ratios on day 2 ; both decreased rapidly in the posttraumatic period, indicating an improvement of the lung situation.

Patient 7. The ratio course of this patient equals that of patient 2. Type (I) protein ratios demonstrated a progressive increase of permeability; type (II) protein ratios showed increasing enzyme release from phagocytes until day 6; nevertheless, the lung situation improved and this patient survived.

\section{Enzyme content of polymorphonuclear leukocytes}

Figure 5 demonstrates the content of lactate dehydrogenase, myeloperoxidase, and elastase enzyme activity, as well as complexed and total elastase concentrations in granulocytes isolated from blood and lavage fluid of patients and normals. Generally, in nearly all measurements the inter-individual scattering was highest in cells isolated from lavage fluids.

\section{Lactate dehydrogenase}

The cytoplasmic lactate dehydrogenase activity was lower in blood-derived cells of the patient group (105.4 U/109 cells), the mean contents of lavagederived cells and normal cells (150.2 and $142.4 \mathrm{U} / 10^{9}$ granulocytes, respectively) being of comparable size.

\section{Myeloperoxidase}

Myeloperoxidase activity in lavage- and bloodderived patient cells were lower (49.2 and $40.7 \mathrm{U} / 10^{9}$ cells, respectively) than in normals $\left(112.8 \mathrm{U} / 10^{9}\right.$ cells $)$.

\section{Elastase activity}

As with myeloperoxidase, the elastase enzyme activity was found to be lower in patient lavage- and bloodderived cells (46.4 and $66.9 \mathrm{U} / 10^{9}$ granulocytes, respectively) in comparison with normals $\left(105.6 \mathrm{U} / 10^{9}\right.$ cells). Together with the myeloperoxidase results, this could be explained by enzyme loss through regurgitation during feeding or by frustrated phagocytosis.

\section{Complexed elastase concentration}

In comparison with normals $\left(1.34 \mu \mathrm{g} / 10^{9}\right.$ cells) the complexed elastase concentrations were markedly elevated in patient blood cells $\left(3.28 \mu \mathrm{g} / 10^{9}\right.$ granulocytes) and drastically increased in lavage-derived patient granulocytes $\left(360.9 \mu \mathrm{g} / 10^{9}\right.$ cells). 

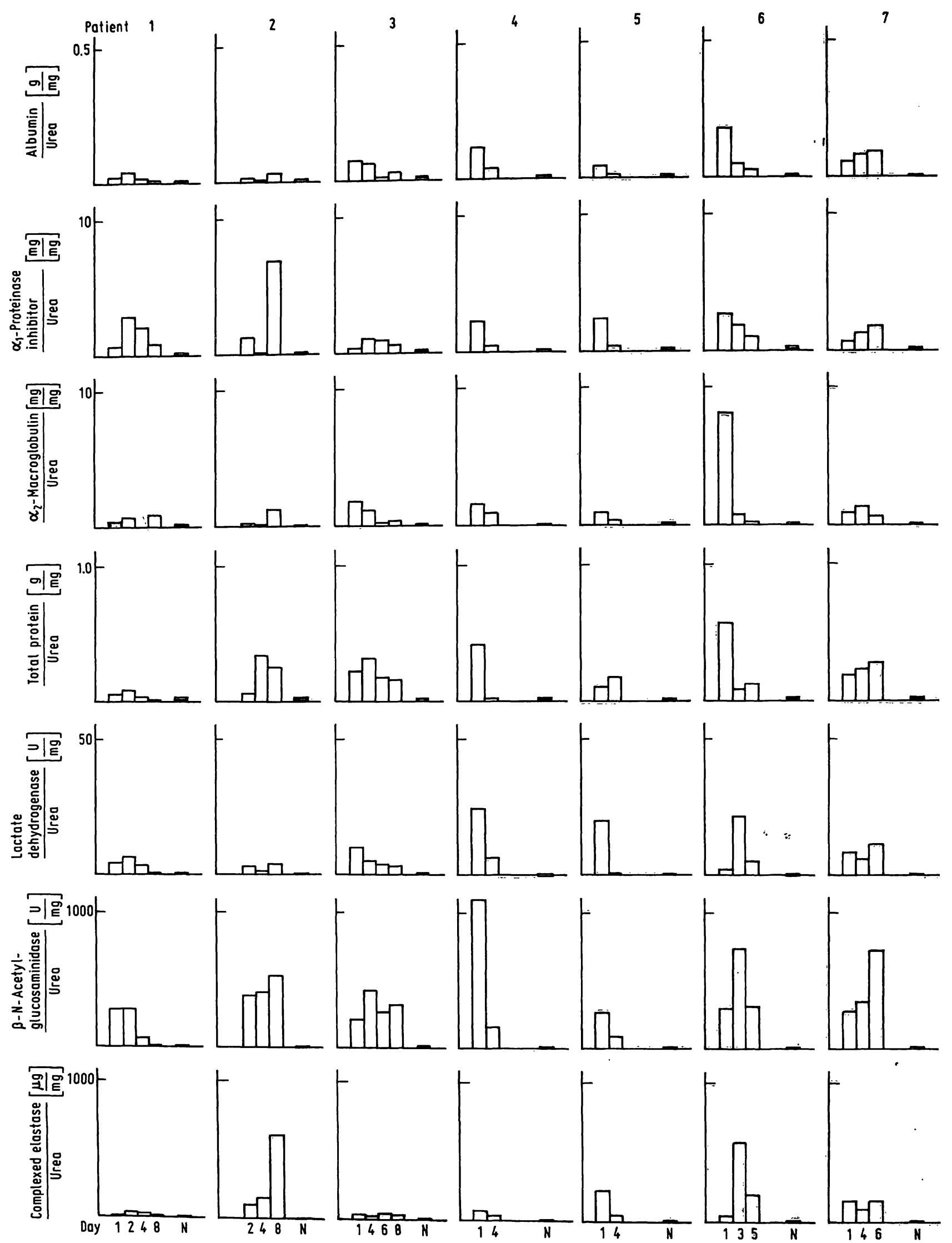

Fig. 4. Posttraumatic course of bronchoalveolar lavage fluid protein/urea ratios of patients $1-7$ abscissa $=$ time of bronchoalveolar lavage procedure (d) $\mathrm{N}$ (black columns) $=$ ratios of normals $(\overline{\mathrm{x}} ; \mathrm{n}=4)$ 


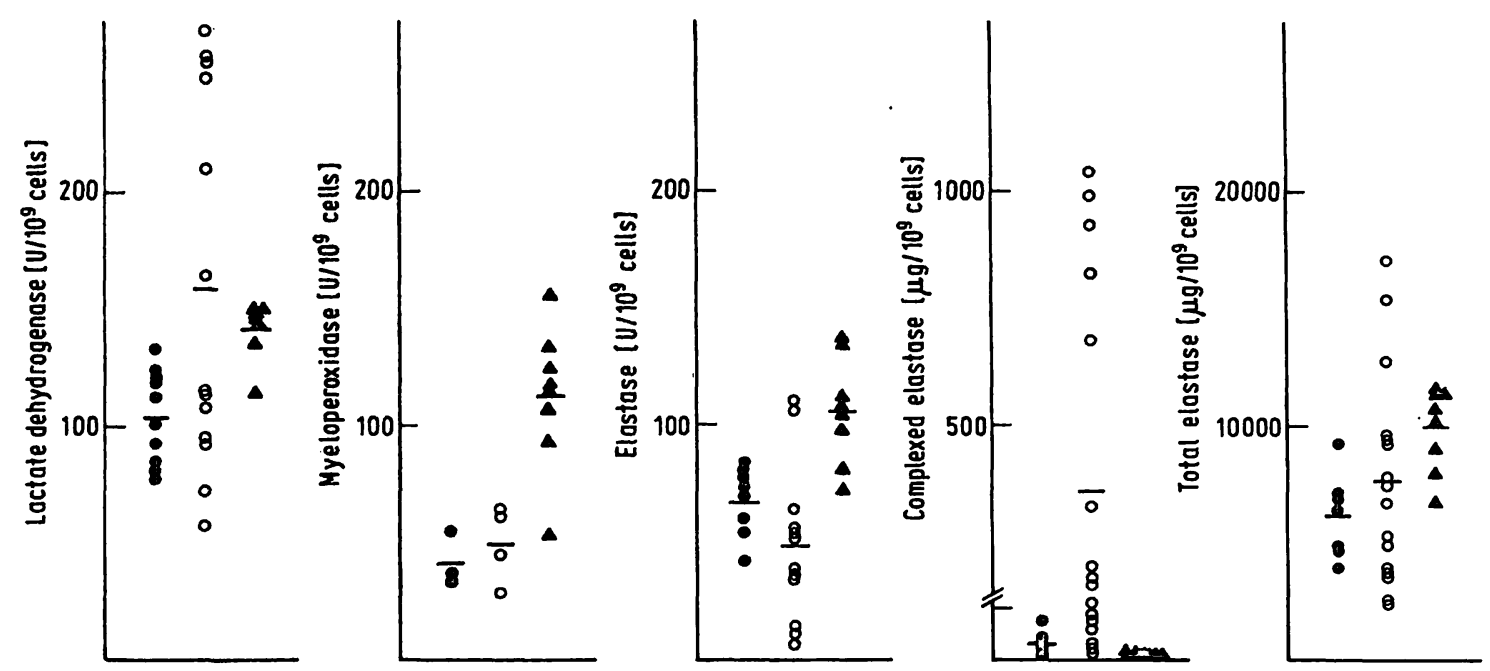

Fig. 5. Enzyme contents of polymorphonuclear leukocytes isolated from blood $(O)$ and bronchoalveolar lavage fluid $(O)$ of seven patients and from blood of eight normals $(\Delta)$

$-=$ means

\section{Total elastase concentration}

The total elastase content of patient blood and lavage granulocytes was lower (6154 and $7684 \mu \mathrm{g} / 10^{9}$ cells, respectively) than in normals $\left(9962 \mu \mathrm{g} / 10^{9}\right.$ cells). This observation may confirm the above speculation about enzyme loss through phagocytic activity.

\section{Chemiluminescence results}

Absence of chemiluminescence data points in the figures indicates that there was an insufficient granulocyte count to investigate.

From chemiluminescence measurements we tried to obtain as much information about the functional status of blood- and lavage-derived granulocytes as possible. The stimulatory capacity of the cells was therefore evaluated as follows:

1. peak maximum counts/min values (CL $1-\mathrm{K} 1)$ : magnitude of maximum photon emission from 25000 granulocytes (CL 1) stimulated by zymosan and $A B$ plasma corrected for the counts/min value produced in absence of zymosan but in presence of $A B$ plasma (K 1)

2. peak time in min:

time required to reach (CL 1); by using a constant opsonin concentration (constant volume of $\mathrm{AB}$ plasma) this time can only vary as a result of changes in granulocyte receptor affinity and/or concentration

3. peak maximum counts/min values (CL 2-K 2): magnitude of maximum photon emission from 25000 granulocytes (CL 2) stimulated by zymosan without
AB plasma addition corrected for the counts/min value produced in the absence of zymosan and $A B$ plasma (K 2)

4. control counts/min (K 1):

magnitude of maximum photon emission from 25000 granulocytes without zymosan in presence of $\mathrm{AB}$ plasma

5. control counts/min (K 2):

magnitude of maximum photon emission from 25000 granulocytes without zymosan or $\mathrm{AB}$ plasma

Figure 6 summarizes the chemiluminescence results. Normal ranges ( $\bar{x} \pm s ; n=8$, shaded areas) were determined for blood-derived granulocytes of normal healthy donors.

Patient 1. In the posttraumatic course lavage-derived granulocyte chemiluminescence showed a distinct maximum of zymosan $+\mathrm{AB}$ plasma-stimulated values above normals, indicating a higher degree of excitability than blood-derived cells.

The time to reach maximum values was prolonged for blood-derived cells on day 4, and extremely shortened for lavage-derived cells. This effect is supposed to have been caused by granulocyte passage across the blood-air barrier, during which the sensitivity of the cells seemed to increase, thus being stimulated faster and to a higher degree. An unusually high degree of stimulation by zymosan without opsonin (AB plasma) was observed on day 4; the controls also had elevated values. An explanation for this phenomenon cannot be given at present. 

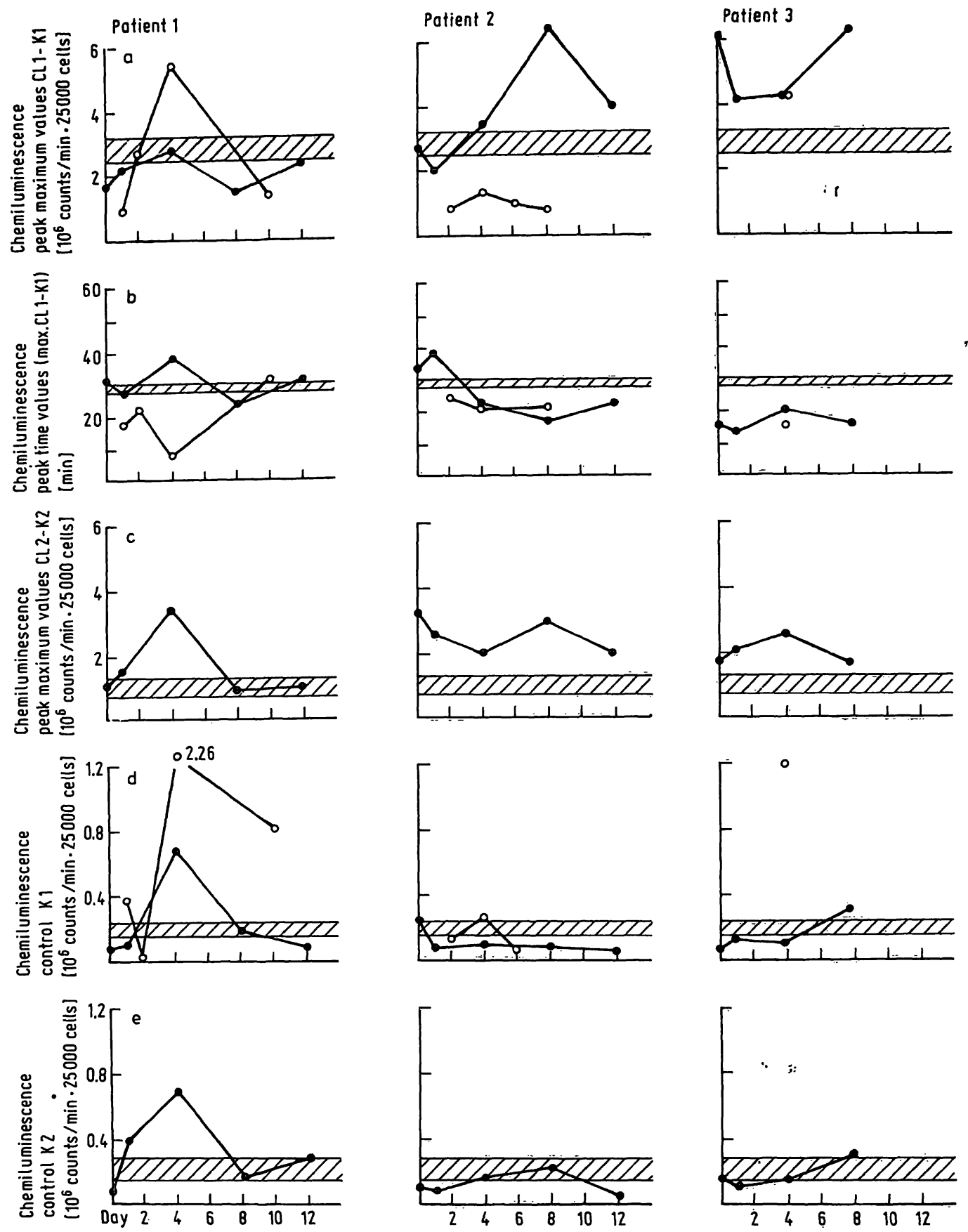

Fig. 6. Course of chemiluminescence data of bronchoalveolar lavage fluid (O) and blood (O) derived polymorphonuclear leukocytes

abscissa $=$ time of bronchoalveolar lavage fluid and blood sampling for polymorphonuclear leukocyte isolation

TIIII $=$ normal range $(\bar{x} \pm s ; n=8)$ of blood-derived polymorphonuclear leukocytes

$\mathrm{CL}=$ chemiluminescence response after stimulation

$\mathrm{K}=$ chemiluminescence response without stimulation (blank)

Patient 2. In this patient quite different behaviour was observed. The stimulatory capacity (CL $1-\mathrm{K} 1)$ was higher for blood- than for lavage-derived granulocytes, especially on day 8 . Beginning on day 2 the reaction times were shortened for both lavage- and blood-derived cells, possibly indicating a receptor alteration. (CL 2-K 2) values were observed to be higher than in normals.
Patient 3. With the exception of day 4 , only blood granulocytes could be studied. During the complete posttraumatic course they were found to be in a state of faster and higher stimulatory capacity compared with normals. The blood-derived cell stimulation by zymosan without $\mathrm{AB}$ plasma was again found to be above that of normals. 

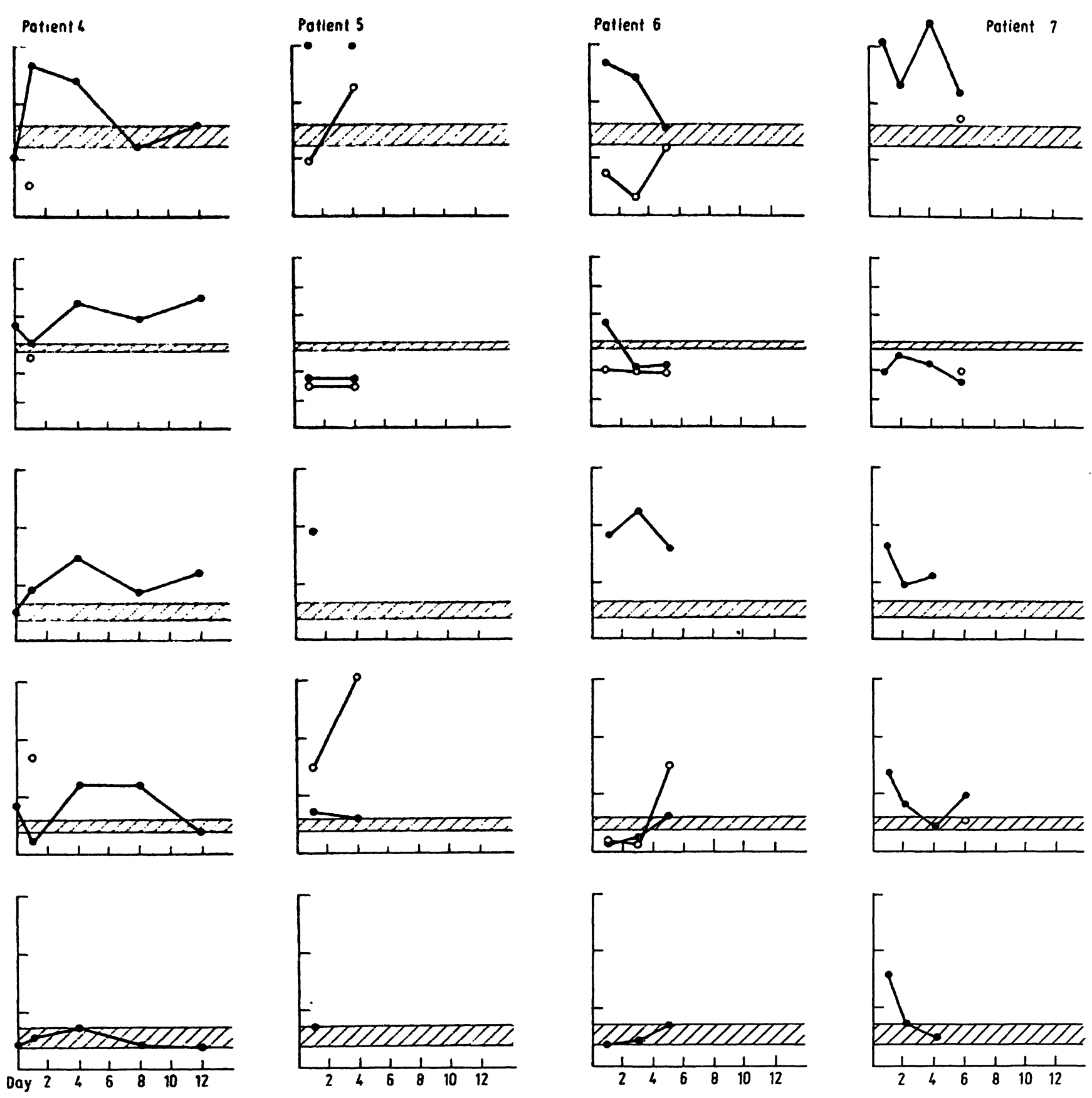

Fig. 6. Continued

Patient 4 . In this patient as well, only blood-derived cells could be investigated with the exception of day 1. The blood granulocytes were excitable to a higher degree of photon emission than normals on days 1 and 4 . This was accompanied by s slower reaction than in normals. Zymosan stimulation without $\mathrm{AB}$ plasma addition was again elevated.

Patient 5. Lavage-derived granulocyte stimulation by zymosan and $A B$ plasma showed an increase from subnormal to supranormal values between days 1 and 4 , accompanied by short reaction times. Bloodderived cell values were several fold higher than those of normals, and increasingly so with time.

Patient 6. (CL 1-K 1) values were found above normals for blood granulocytes and below normals for lavage granulocytes with a tendency towards normalization throughout the course. Photon emission times were low for lavage cells during the whole course, whereas blood-derived cell times were higher on day 1 and lower on days 3 and 5 as compared with normals. (CL 2-K 2) values were several fold higher than those of normals.

Patient 7. In comparison with the only lavage granulocyte value on day 6 the blood granulocyte stimulatory potentials was found to be far above the normal range and the stimulation times were below the normal range. As for the majority of patients, the zymosan-stimulated chemiluminescence without $A B$ plasma was above normal values. 
Figure 7 comprises all chemiluminescence patient data by projecting corresponding values of the same parameter on to a single figure. From this, semiquantitative conclusions were drawn: The stimulation by zymosan and $A B$ plasma of blood-derived granulocytes produced a chemiluminescence response usually above that of normals, while the chemiluminescence response of lavage-derived granulocytes was below that for normals. Stimulatory times seemed to be below the normal range for lavage-derived cells and both above and below the value for normals for blood-derived cells. The range of stimulatory response of patients' blood granulocytes to zymosan and without $\mathrm{AB}$ plasma was clearly above the normal range. Control values (K 2) without zymosan and $\mathrm{AB}$ plasma were generally within the normal range, whereas controls (K 1 ) without zymosan and with $\mathrm{AB}$ plasma were not consistently distributed either above or below the normal range.

\section{Discussion}

In addition to its acceptance as a technique for the diagnosis, staging, and follow-up of interstitial lung diseases, bronchoalveolar lavage has gained importance as a research tool for evaluating the dynamic inflammatory and immune mechanisms operating in the local environment of the lung. A serial analysis of soluble and cellular components in lavage fluid as well as in blood is therefore useful. In a group of traumatized patients predisposed to the development of the Adult Respiratory Distress Syndrome (İnjury Severity Score $>30$ ) the course of lavage and blood component concentrations as well as lavage cell pattern shifting and alterations of enzyme contents and chemiluminescence response of lavage- and bloodderived polymorphonuclear leukocytes were monitored. Although no patient subsequently developed the severe Adult Respiratory Distress Syndrome pro-
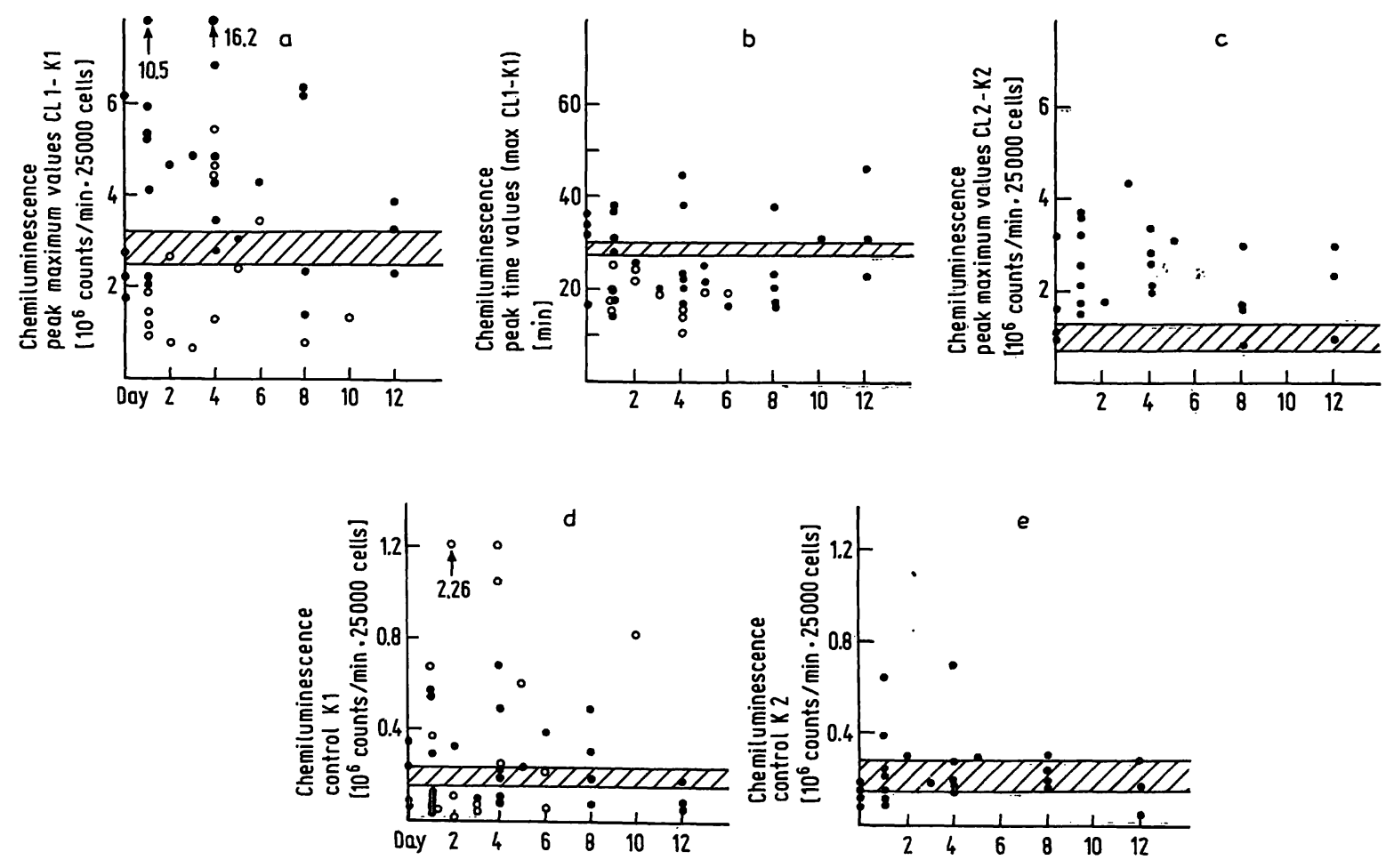

Fig. 7. Combination of all chemiluminescence data

$\boldsymbol{O}$ = blood-derived polymorphonuclear leukocyte chemiluminescence

$\mathrm{O}=$ bronchoalveolar lavage fluid-derived polymorphonuclear leukocyte chemiluminescence

चiाi $=$ normal range $(\overline{\mathrm{x}} \pm \mathrm{s}, \mathrm{n}=8)$

abscissa $=$ time of bronchoalveolar lavage fluid and blood sampling

$\mathrm{CL}=$ chemiluminescence response after stimulation .

$\mathrm{K}=$ chemiluminescence response without stimulation (blank) 
gressing to death, bronchoalveolar lavage fluids of the non-contused part of the lung clearly indicated distinct signs of inflammation and differentiation during the posttraumatic course. In comparison with normals (1) the bronchoalveolar lavage cell distribution was altered towards an increased number of lymphocytes and a markedly increased number of polymorphonuclear leukocytes as evidence of inflammation. The lactate dehydrogenase activity found in the patients' lavage fluids greatly exceeded the transudated portion, indicating enzyme release by cell damage in the interstitial-alveolar space. To judge whether only granulocyte lysis contributed to the lavage fluid's enzyme concentration, the hypothetical number of totally damaged granulocytes was calculated from elastase- $\alpha_{1}$-proteinase inhibitor complex, $\beta-\mathrm{N}$-acetyl-glucosaminidase and lactate dehydroge-
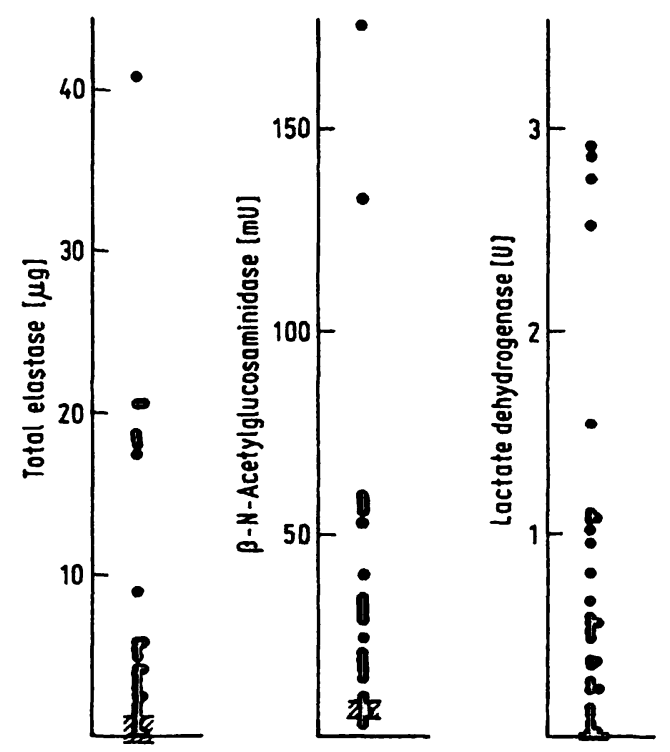

Fig. 8. Elastase (as total protein) and $\beta-\mathrm{N}$-acetyl-glucosaminidase and lactate dehydrogenase activities in patient bronchoalveolar lavage fluid

IIIIE $=$ normal ranges $(\bar{x} \pm s ; n=4)$

Hypothetical number of originally present and totally destroyed polymorphonuclear leukocytes calculated from total elastase, $\beta$ - $\mathrm{N}$-acetyl-glucosaminidase and lactate dehydrogenase contents in bronchoalveolar lavage fluids of seven patients

Number of polymorphonuclear leukocytes $\left(10^{6}\right)$

\begin{tabular}{|c|c|c|c|}
\hline & \multicolumn{3}{|c|}{ According to } \\
\hline & $\begin{array}{l}\text { total } \\
\text { elastase }\end{array}$ & $\begin{array}{l}\text { B-N-acetyl- } \\
\text { glucosaminidase }\end{array}$ & $\begin{array}{l}\text { lactate } \\
\text { dehydrogenase }\end{array}$ \\
\hline$\overline{\mathbf{x}}$ & 0.79 & 24.1 & 5.75 \\
\hline $\mathbf{s}$ & 0.95 & 26.8 & 6.28 \\
\hline $\mathrm{n}$ & 27 & 27 & 28 \\
\hline
\end{tabular}

Normal contents $(\bar{x}$ from $n=8$ ) served as a reference:

$9.96 \mu \mathrm{g}$ elastase- $\alpha_{1}$-proteinase inhibitor $1.45 \mathrm{mU} \beta-\mathrm{N}$-acetyl-glucosaminidase 0.14 U lactate dehydrogenase nase contents in patient lavage fluids by using the normal values as also determined in this study. The results are presented in figure 8 . From the granulocyte-specific elastase concentrations of all patient lavage fluids a mean of $0.79 \cdot 10^{6}$ totally lysed polymorphonuclear leukocytes was calculated. Based on the $\beta$-N-acetyl-glucosaminidase (and lactate dehydrogenase) content a mean of $24.1 \cdot 10^{6}\left(5.75 \cdot 10^{6}\right)$ granulocytes was calculated. This leads to the conclusion that cells other than polymorphonuclear leukocytes, presumably alveolar macrophages, took part in the liberation of the enzymes. In order to overcome the variability of lavage fluid sampling and the difficulty of comparing lavage protein concentrations, all concentration values were related to urea as an internal reference substance instead of to albumin (17) or an external reference such as methylene blue (18). By this method the albumin/urea and $\alpha_{1}$-proteinase inhibitor/ urea ratios in lavage fluid and plasma clearly indicated an increased permeability of the blood-air barrier. $\alpha_{2}$-Macroglobulin/urea and total protein/urea ratios did not -demonstrate such a change. On the other hand, lactate dehydrogenase, $\beta$ - $\mathrm{N}$-acetyl-glucosaminidase, and elastase were predominantly released by phagocytes rather than transudated from plasma. Thus, $\beta$ - $\mathrm{N}$-acetyl-glucosaminidase and elastase could be used as markers of the degree of predisposition to lung injury development (e. g. Adult Respiratory Distress Syndrome), that may be initiated by neutral proteases like elastase $(3,7)$.

Careful consideration of type (I) and type (II) lavage protein/urea ratios could allow the prediction of improvement or deterioration of the patients' lung situation. In comparison to normals, decreased myeloperoxidase and elastase activities, as well as elastase concentrations of patient lavage- and blood-derived polymorphonuclear leukocytes, demonstrated enzyme loss, presumably through phagocytosis. Complexed elastase was found to be more than 100 fold elevated in lavage-derived granulocytes. Further investigations are needed to elucidate whether polymorphonuclear leukocytes are able, like macrophages to incorporate free or complexed elastase by phagocytosis $(19-21)$.

From chemiluminescence data it was evident that lavage-derived granulocytes had partially lost stimulatory capacity, in comparison with above normal activity in blood-derived cells. Furthermore, lavage granulocytes seemed to acquire an increased receptor efficiency during blood-air passage, documented by shortened photon emission times. The migration of polymorphonuclear leukocytes from blood to alveolus seemed to be linked with a transformation process that resulted in a less aggressive type of cells 
with respect to stimulatory mechanisms which release toxic and damaging mediators of lung injury. Such altered granulocytes are believed to be exhausted, their content partially released into the lavage fluid and their chemiluminescence response diminished.

This is supported by the simultaneous comparison of lavage type (II) protein/urea ratios and the stimulatory capacities of lavage- and blood-derived polymorphonuclear leukocytes. In patient 2 on day 8 when

\section{References}

1. Hunninghake, G. W., Gadek, J. E., Kawanami, O., Ferrans, V. J. \& Crystal, R. G. (1979) Am. J. Pathol. 97, 149-206.

2. Daniele, R. P., Elias, J.A., Epstein, P. E. \& Rossman, M. D. (1985) Ann. Intern. Med. 102, 93-108.

3. Lee, C. T., Fein, A. M., Lippmann, M., Holtzman, H., Kimbel, P. \& Weinbaum, G. (1981) N. Engl. J. Med. 304, 192-196.

4. Schraufstatter, I., Revak, S. D. \& Cochrane, C. G. (1984) Fed. Proc. 43, 2807-2810.

5. Merritt, T. A., Cochrane, C. G., Holcomb, K., Bohl, B., Hallman, M., Strayer, D., Edwards III, D. K. \& Gluck, L. (1983) J. Clin. Invest. 72, 656-666.

6. Ogden, B. E., Murphy, S. A., Saunders, G. C., Pathak, D. \& Johnson, J. D. (1984) Am. Rev. Respir. Dis. 130, $817-821$.

7. Janoff, A. (1985) Annu. Rev. Med. 36, 207-216.

8. Bernhard, G. R. \& Brigham, K. L. (1985) Annu. Rev. Med. 36, 195-205.

9. McGuire, W. W., Spragg, R. G., Cohen, A. B. \& Cochrane, C. G. (1982) J. Clin. Invest. 69, 543-553.

10. Hjorth, R., Jonsson, A. \& Vretblad, P. (1981) J. Immunol. Methods 43, 95-101.

11. Kingsley, G. R. (1939) J. Biol. Chem. 131, 197-200.
$\beta-\mathrm{N}$-acetyl-glucosaminidase and elastase concentrations were at their highest, the simultaneous chemiluminescence response exhibited a maximal difference between the stimulatory functions of blood (highest) and lavage (lowest) granulocytes. Exactly the same correlation was observed in patient 4 (day 1 ) as well as in patient 5 (days 1 and 4), and in patient 6 (days 1 and 3). This striking relationship needs to be confirmed by further studies on patients developing severe Adult Respiratory Distress Syndrome.
12. Schirardin, H. \& Ney, J. (1972) Z. Klin. Chem. Klin. Biochem. 10, 338- 344 .

13. Henson, P. M., Zanolari, B., Schwartzman, N. A. \& Hong, S. R. (1978) J. Immunol. 121, 851-855.

14. Yatziv, S., Kahane, I., Abeliuk, P., Cividalli, G. \& Rachmilewitz, E. A. (1979) Clin. Chim. Acta 96, 67-72.

15. Crystal, R. G., Gadek, J. E., Ferrans, V. J., Fulmer, J. D., Line, B. R. \& Hunninghake, G. W. (1981) Am. J. Med. 70, 542-568.

16. White, R., Janoff, A. \& Godfrey, H. P. (1980) Lung 158, 9-14.

17. Reynolds, H. Y., Fulmer, J. D., Kazmierowski, J. A., Roberts, W. C., Frank, M. M. \& Crystal, R. G. (1977) J. Clin. Invest. 59, 165-175.

18. Baughman, R. P., Bosken, C. H., Loudon, R. G., Hurtubise, P. \& Wesseler, T. (1983) Am. Rev. Respir. Dis. 128, $266-270$.

19. Debanne, M. T., Bell, R. \& Dolovich, J. (1975) Biochim. Biophys. Acta 411, 295-304.

20. Dolovich, J., Debanne, M. T. \& Bell, R. (1975) Am. Rev. Respir. Dis. 112, 521-525.

21. Campbell, E. J., White, R. R., Senior, R. M., Rodriguez, F. J. \& Kuhn, C. (1979) J. Clin. Invest. 64, 824-833.

Dr. Alexander Dwenger :

Abteilung für Klinische Biochemie

Medizinische Hochschule Hannover

Konstanty-Gutschow-Straße 8

D-3000 Hannover 61 